Research Report

\title{
Development of Illustration Book on Dental and Oral Healthy in Children (Community Empowerment)
}

\author{
Zhara Robyana $^{1}$, Adellia Monica Chandra ${ }^{1}$, Betadion Rizki Sinaredi ${ }^{2}$, Taufan Bramantoro ${ }^{1}$ \\ ${ }^{1}$ Department of Public Dental Health, Faculty of Dental Medicine, Universitas Airlangga, Surabaya, Indonesia \\ ${ }^{2}$ Department of Pediatric Dentistry,Faculty of Dental Medicine, Universitas Airlangga, Surabaya, Indonesia
}

\begin{abstract}
Background: Dental caries is a disease that affects all ages, including early childhood. According to the World Health Organization (WHO), the incidence of dental caries in Indonesian children aged 5 and 6 years in 2017-2018 reached $70 \%$ or more. Parental education in dental health from an early age plays a vital role. One of the easy-to-understand educational media is a picture book. Purpose: This engagement activity was conducted to increase parental participation in the development of a picture book to meet the needs of dental health education for early childhood at Omah Cilik Fundaycare Surabaya Methods: This activity was an online educational activity involving parents. It was a sharing session between participants and informants about early childhood dental and oral health problems. The increased participation of participants was assessed using a Google form when the activity was going on. Results: This activity revealed that $100 \%$ of participants were enthusiastic about getting the latest information about children's oral health, and more than $70 \%$ had the correct answers. Conclusion: Participants are quite enthusiastic and active during online discussions.
\end{abstract}

Keywords: picture book; education; dental health; early childhood; development

Correspondence: Taufan Bramantoro, Department of Public Dental Health, Faculty of Dental Medicine, Universitas Airlangga, Jl. Prof. Dr. Moestopo No. 47 Surabaya, 60132, Indonesia, Email: taufanbram@gmail.com

\section{INTRODUCTION}

The growth of primary teeth in early childhood appears at the age of six months, and at the age of 30 months, the 20 primary teeth were complete. ${ }^{1}$ The majority of thriving children's teeth will contribute to their health and wellbeing. However, teeth that are damaged and sometimes destroyed in some children will result in dental caries. ${ }^{2}$ Dental caries can also cause discomfort in children, and thus they can interfere with daily activities.

Dental caries is a disease that attacks teeth at all ages, including early childhood. It attacks the primary teeth (milk teeth) and permanent teeth. Children and adults have different dental caries because of their rapid development, depending on risk factors and their control. It is a noncommunicable disease that can be prevented and most commonly affects children worldwide. ${ }^{2-4}$

Based on data from the WHO Collaborating Center for Community Oral Health Program and Research, University of Copenhagen, the percentage of dental caries in Indonesian children aged 5 and 6 years in 2017-2018 reached $70 \%$ or more. ${ }^{5}$ Meanwhile, according to the Basic Health Research data in 2018, dental caries in early childhood in the age range of 5-6 years reached $93 \%$. This means that only $7 \%$ of early childhood in Indonesia are free from dental caries. ${ }^{6}$
Dental caries in early childhood can be prevented, one of which is through the active role of parents. They must be good at choosing child dental health education because their children's dental health may be obstructed if it is not given early. Dental health education can be delivered through a picture book. This kind of media is in great demand and easy to understand because of having two elements, namely verbal and visual. ${ }^{7}$ The most apparent advantage of an picture book as a health promotion media compared to other media is its power to increase readers' curiosity as learning motivation. The images presented play a role in stimulating the reader's interest. Messages are easier to convey, and thus they can be used as learning alternatives. ${ }^{8}$ Therefore, this engagement activity aims to increase parents' knowledge and role in developing an picture book to meet the needs of dental health education for early childhood at Omah Cilik Fundaycare Surabaya.

\section{MATERIALS AND METHODS}

This community service activity was online discussion about child dental health emergencies and myths and facts about child dental health involving 31 respondents. The subjects of this activity were parents with children aged 
$\leq 6$ years, especially those at Omah Cilik Fundaycare Surabaya City.

The moderator opened this activity and then followed by a two-way discussion between participants and experts in their fields as the source person. This activity was attended by parents and partners of Omah Cilik Fundaycare Surabaya through a zoom meeting. The e-picture book entitled "50 Myths and Facts about Children's Dental Health" was provided. This activity aimed to increase the active role of parents in early childhood dental health education. Evaluation of this activity was carried out through an online form provided during online sharing.

\section{RESULTS}

The results of the Parent's Sharing Session attended by the parents and partners of Omah Cilik Fundaycare were presented in this part. The results showed that the participants were very enthusiastic about getting the latest information about child dental health. It can be seen from all participants were willing to get new information. From the questions given, more than $70 \%$ had correct answers. This revealed that online sharing participants were active (Table 1).

Table 1. Respondents' answers about child dental emergency and myth and facts about child dental health

\begin{tabular}{lcc}
\hline Statement & Willing & Not willing \\
\hline $\begin{array}{l}\text { Willing to get the latest information } \\
\text { about children's dental health }\end{array}$ & $100 \%$ & $0 \%$ \\
\hline Statement & True & False \\
\hline $\begin{array}{l}\text { Factors that affect cavities } \\
\begin{array}{l}\text { What to do when your children } \\
\text { have a toothache }\end{array}\end{array}$ & $81 \%$ & $19 \%$ \\
$\begin{array}{l}\text { Prevention of children's toothache } \\
\text { at night }\end{array}$ & $81 \%$ & $22 \%$ \\
$\begin{array}{l}\text { What to do when your children's } \\
\text { tooth hurt }\end{array}$ & $84 \%$ & $19 \%$ \\
Golden hour time & $78 \%$ & $31 \%$ \\
\hline
\end{tabular}

\section{DISCUSSION}

The community service was aimed at increasing the role of parents in child dental health. It showed that they were enthusiastic about the care and supervision of child dental health. It was indicated by all parents were willing to get the latest information about their children's health. Previous research has stated that parental knowledge, especially mothers, relates to parenting or care in preventing dental caries in early childhood. ${ }^{9}$ If someone has good knowledge, they will take good actions. A mother with good knowledge about child dental and oral health will teach her children as early as possible about preventing dental caries. ${ }^{10,11}$ Several previous studies state that knowledge is a critical domain in shaping one's actions; therefore, an action made based on knowledge is better than an action made without knowledge. ${ }^{12}$ Therefore, the better mother's knowledge about dental and oral health, the better the dental and oral health of the child. ${ }^{13-15}$ Additionally, knowledge and attitudes can also increase the intentions and behavior of parents, especially mothers, in teaching more effective tooth brushing practices to their children. ${ }^{16}$

Speaking about participants' answers regarding dental and oral health for early childhood, among 31 participants, more than $70 \%$ answered correctly. It revealed that participants had a good understanding of child dental and oral health. It may be due to the selection of educational media and information obtained by parents. For example, they choose a reading source that is easy to understand; the information can be received and taken into action correctly. The educational media used in this activity is an picture book.

Picture book plays a vital role in presenting the story in pictures, representing the story, and expanding the story without duplicating the text to make readers easily understand. Moreover, picture book encourages readers to enjoy reading until the last page. ${ }^{17}$ Several studies have stated that picture book is worthy of use in increasing reader knowledge. ${ }^{18-20}$ The extended picture books help parents provide education in early childhood. Parents will implicitly invite their children to practice dental and oral hygiene in everyday life.

\section{CONCLUSION}

The program of extended picture book as an education for dental and oral health in early childhood for parents of Omah Cilik Fundaycare Surabaya was conducted online. The participants were pretty enthusiastic and active in the discussion as indicated by more than $70 \%$ correct answers. Similar programs can be carried out with more exciting presentations and illustrations to increase parents' interest in understanding child dental health.

\section{ACKNOWLEDGEMENT}

We thanked Omah Cilik Fundaycare Surabaya City for collaborating with us in the community activity.

\section{REFERENCES}

1. ADA. Baby Teeth Eruption Charts. American Dental Association. 2021 [cited 2021 Oct 27]. Available from: https:// www.mouthhealthy.org/en/az-topics/e/eruption-charts

2. WHO. Ending childhood dental caries: WHO implementation manual. Geneva: World Health Organization; 2019. Licence: CC BY-NC-SA 3.0 IGO. Geneva; 2019. 57 p. Available from: https://www.who.int/publications/i/item/ending-childhooddental-caries-who-implementation-manual

3. Otero G, Pechlaner G, Liberman G GE. The neoliberal diet and inequality in the United States. Soc Sci Med. 
2015;142:47-55.

4. Thomson WM. Public health aspects of paediatric dental treatment under general anaesthetic. Dent J. 2016;4(2).

5. Petersen PE. WHO Collaborating Centre for Community Oral Health Programme and Research, University of Copenhagen. 2019.

6. Kementerian Kesehatan Republik Indonesia. Riset Kesehatan Dasar Tahun 2018. 2018.

7. Soedarso N. Perancangan buku ilustrasi perjalanan mahapatih gajah mada. Vis Commun Des BINUS Univ. 2014;5(2):566.

8. Haq Z. Penggunaan Komik Kesehatan Gigi Dalam Meningkatkan Pengetahuan Dan Kepercayaan Siswa Kelas V Sdn Martopuro 01 Kecamatan Purwosari Kabupaten Pasuruan. J PROMKES. 2017;3(2):124-133.

9. Pinat LMA, Setijanto D, Bramantoro T. The correlation between mother's knowledge and parenting toward childhood caries in the remote area. J Int Dent Med Res. 2017;10(3):905-8.

10. Nurdan C, Has E. The evaluation of the effects of sociodemographic factors on oral and dental health: A study on the ages 6-12. Procedia - Soc Behav Sci. 2015;195:20-5.

11. Sanders M, Morawska A. Can changing parental knowledge, dysfunctional expectations and attributions, and emotion regulation improve outcomes for children. Parenting skills. Univ Queensland, Aust. 2014;2:1-4.

12. Amin M, Nyachhyon P, Elyasi M, Nuami M. Impact of an oral health education workshop on parents oral health knowledge, attitude and perceived bevavioral control among African immigrants. J oral Dis. 2014;5:10-5.
13. Hooleya M, Skouterisa H, Boganina C, Saturb J, Kilpatrickc. Parental Influence and the developmet of dental caries in children aged 0-6 years: a system review of the literature. J Dent. 2012;40(10):873-85.

14. Bazorgmehr E, Hajizamni A, Mohammadi T. Oral health behavior of parents as a predictor of oral health status of their children. Hindawi Publ corparition ISRN Dent. 2013;10-2.

15. Abdat M, Ramayana I. Relationship between mother's knowledge and behaviour with oral health status of early childhood. Padjadjaran J Dent. 2020;32(3):166.

16. Setijanto RD, Bramantoro T, Palupi R, Hanani A. The role of attitude, subjective norm, and perceived behavioral control (PBC) of mothers on teaching toothbrushing to preschool children - Based on the Theory of Planned Behavior: A crosssectional study. Fam Med Prim Care Rev. 2019;21(1):53-7.

17. Brickhouse T. Family Oral Health Education. In: Early Childhood Oral Health. Wiley-Blackwell; 2009. p. 198-218.

18. Yuliana. Pengambangan Buku Cerita Bergambar Sebagai Bahan Ajar Dalam Perkembangan Moral Anak Usia Dini Taman Kanak-Kanak Islamiyah Desa Tanjung raja. Universitas Islam Negeri Raden Intan. 2018;97.

19. Sania R. Media Buku Cerita Bergambar Berbasis Pop-up untuk Meningkatkan Keterampilan Membaca Cepat Bahasa Indonesia SDN Beji 02 Ungaran. Univ Negeri Semarang. 2020;113.

20. Wulandari C. Pengambangan Buku Cerita Bergambar Berbasis Pendidikan Lingkungan Hidup Untuk Pembelajaran Membaca Siswa Kelas 1 SD. Univ Sanata Dharma Yogyakarta. 2017;113-4. 